\title{
Hubungan Antara Kepribadian Agreeableness Dengan Kinerja Karyawan Di Pt. Haleyora Power Singkarak Sumatera Barat
}

\author{
Elvia Mun Nanda, Herio Rizki Dewinda, Isna Asyri Syahrina \\ Universitas Putra Indonesia "YPTK" Padang \\ email: Elvia.via97@gmail.com hrdewinda@gmail.com isna_syeko@yahoo.com
}

\begin{abstract}
The study aims to determine the relationship between personality Agreeableness and employee performance at PT. Haleyora Power Singkarak, West Sumatra. The independent variable in this study is personality Agreeableness and the dependent variable is Employee Performance. The measuring instrument used in this study is the personality Agreeableness scale and Employee Performance scale. The sampling technique in this study used a saturated sample technique. The sample in this research is 40 employee in PT. Haleyora Power Singkarak, West Sumatera. Validity and reliability test in this study using Alpha Cronbach technique. The results of the validity coefficient on the personality Agreeableness scale move from rix $=0.316$ to 0.733 , with a reliability coefficient of $\alpha=0.873$, while the Employee Performance Scale moves from rix $=0.362$ to 0.770, with a reliability coefficient of $\alpha=0.932$. Based on data analysis, the value of the correlation between personality Agreeableness and the employee's performance is 0.556 with a significance level of 0,000. The results of the analysis of the effective contribution of the personality Agreeableness variable to employee performance were $31 \%$.
\end{abstract}

Keyword: Personality Agreeableness, Employee Performance

\begin{abstract}
Abstrak
Penelitian ini bertujuan untuk mengetahui hubungan antara Kepribadian Agreeableness dengan Kinerja karyawan Di PT. Haleyora Power Singkarak Sumatera Barat. Variabel bebas dalam penelitian ini adalah Kepribadian Agreeableness dan variabel terikat adalah Kinerja Karyawan. Alat ukur yang digunakan dalam penelitian ini adalah skala Kepribadian Agreeableness dan skala Kinerja Karyawan. Teknik pengambilan sampel dalam penelitian ini menggunakan teknik Sampel jenuh. Sampel dalam penelitian ini adalah 40 karyawan PT. Haleyora Power Solok. Uji validitas dan reliabilitas pada penelitian ini menggunakan teknik Alpha Cronbach. Hasil koefisien validitas pada skala Kepribadian Agreeableness bergerak dari $\mathrm{r}_{\mathrm{ix}}=0,316$ sampai dengan 0,733, dengan koefisien reliabilitas sebesar $\alpha=0,873$, sedangkan pada Skala Kinerja Karyawan bergerak dari $\mathrm{r}_{\mathrm{ix}}=0,362$ sampai dengan 0,770, dengan koefisien reliabilitas sebesar $\alpha=0,932$. Berdasarkan analisis data, diperoleh nilai korelasi antara Kepribadian Agreeablenes dengan kinerja karyawan sebesar 0,556 dengan taraf signifikansi 0,000. Hasil analisis sumbangan efektif variabel Kepribadian Agreeablenes dengan kinerja karyawan adalah sebesar $31 \%$.
\end{abstract}

Kata kunci: Kepribadian Agreeableness, Kinerja Karyawan

\section{Pendahuluan}

Di era globalisasi seperti saat ini, sumber daya manusia (SDM) sangat menentukan keberhasilan perusahaan, maka selayaknya SDM tersebut dikelola sebaik mungkin. Keberhasilan sebuah perusahaan atau organisasi tidak hanya dari keunggulan teknologi yang memadai, namun faktor manusia merupakan hal yang cukup penting, SDM akan semakin berkembang seiring dengan berkembanganya teknologi salah satunya seperti sumber daya listrik. 
Ketersediaan tenaga listrik merupakan aspek yang sangat penting dan bahkan menjadi suatu parameter untuk mendukung keberhasilan pembangunan suatu daerah. Pengelolaan sumber daya energi listrik yang tepat dan terarah dengan jelas akan menjadikan potensi yang dimiliki suatu wilayah berkembang dan termanfaatkan secara optimal. Oleh karena itu, perencanaan dan pengelolaan energi secara umum termasuk di dalamnya adalah energi listrik perlu mendapatkan perhatian serius dari Pemerintah Daerah. Hal tersebut tentu juga seiring dan searah dengan peningkatan peran Pemerintah Daerah dalam mengelola sumber daya energi. Di Indonesia, penyaluran tenaga listrik keseluruh wilayah dikelola oleh perusahaan negara yaitu perusahaan yang sekarang berbentuk Perusahaan Umum Listrik Negara yang kita kenal namanya PT. PLN (Persero) (dalam Khan, 2014) ${ }^{[11]}$

PT PLN (Persero) bergerak dalam bidang penyediaan tenaga listrik yang keberadaannya sangat dibutuhkan oleh masyarakat. Sebagai salah satu instrumen dalam pembangunan, keberadaan BUMN di Indonesia dirasakan sangat penting, tidak hanya oleh pemerintah tapi juga oleh masyarakat luas. Dari sisi pemerintahan BUMN seringkali digunakan sebagai salah satu instrumen penting dalam pembangunan ekonomi, khususnya pembangunan dibidang industriindustri manufaktur, dan lain sebagainya. Sementara dari sisi masyarakat, BUMN merupakan instrumen yang penting sebagai penyedia layanan yang cepat, murah, dan efisien. Maka dari itu PT PLN (Persero) selalu berupaya untuk terus memperbaharui kinerja dalam memberikan pelayanan yang semakin optimal, sehingga citra PT PLN (Persero) dimata masyarakat akan selalu dinilai baik dan memberikan pelayanan yang baik sehingga memuaskan (dalam Hastuti, 2014) ${ }^{[9]}$ Setiap tahunnya kebutuhan akan listrik di Indonesia terus meningkat, sebagai akibat dari peningkatan kualitas kesejahteraan masyarakat diiringi juga oleh perkembangan industri di Indonesia. Sementara PT. PLN (Persero) memiliki keterbatasan dalam memenuhi peningkatan akan kebutuhan listrik tersebut (dalam Taufik, 2016) ${ }^{[19]}$.

Namun tentunya PT. PLN (Persero) terus-menerus tetap melakukan upaya untuk memenuhi kebutuhan listrik secara bertahap keseluruh pelosok negeri, begitupun dengan perusahaanperusahaan yang merupakan anak dari PT. PLN (Persero) yang didirikan dan lebih dituntut untuk keperluan umum. Kinerja perusahan dipengaruhi oleh para karyawannya, untuk itu karyawan sebagai SDM merupakan sumber daya yang sangat vital bagi perusahaan. Seperti halnya PT. Haleyora Power. PT. Haleyora Power bergerak dibidang pengecekan dan pengelolaan bagi masyarakat yang dituntut untuk selalu memberikan kualitas dalam proses kerjanya dan proses pelayanan terhadap masyarakat, sehingga masyarakat sebagai konsumen akan merasa terpuaskan. Dengan konsumen yang luas, semakin menuntut perusahaan senantiasa memberikan pelayanan yang baik, sehingga beban kerja karyawan menjadi lebih besar, untuk mampu menghasilkan manajemen yang baik, perusahaan harus terus meningkatkan kemampuan sumber daya manusianya untuk hasil kerja optimal. Pada suatu perusahaan, untuk kelancaran dan dapat menghasilkan motivasi kerja yang baik maka diperlukan adanya tujuan dan hasil yang hendak dicapai.

Berdasarkan hasil observasi dan wawancara peneliti pada tanggal 08 Mei 2019 dengan Supervisor PT. Haleyora Power yang mengatakan bahwa terdapat kinerja karyawan yang menurun, disebabkan oleh beberapa karyawan yang tidak bertanggung jawab atas tugas yang dikerjakan dilihat dari masalah karyawan yang cendrung menunda-nunda pekerjaan saat mendapatkan tugas pengecekan kerumah-rumah warga, bahkan sebagian karyawan tidak ditemukan diperusahaan pada saat adanya tugas dan karyawan yang kurang mau untuk mengerjakan tugas atau pekerjaan 
secara kerja sama dan lebih memilih untuk melakukan pekerjaannya sendiri, bahkan sering juga menyendiri disaat teman-temannya yang lain sedang berkumpul ataupun sedang makan siang bersama bahkan ada juga karyawan yang memainkan ponsel saat didalam perusahaan atau ruangan dan tidak menghiraukan siapapun yang melewatinya, serta karyawan tidak disiplin dalam bekerja dapat diperhatikan pada saat ketidaktepatan waktu dalam absensi pagi maupun saat setelah istirahat.

Hasil observasi yang dilakukan pada tanggal 09 Mei 2019 yaitu adanya karyawan yang tidak ramah bahkan tidak peduli kepada konsumen yang datang baik untuk pengaduan adanya kerusakan, adapun beberapa orang karyawan yang sibuk dengan urusannya masing-masing sehingga pada saat adanya pekerjaan mereka lambat dalam penanganannya, adapun saat dilapangan beberapa karyawan merasa cemas saat harus memanjat tiang listrik atau memperbaiki kabel-kabel yang terputus, pada saat pekerjaan tersebut tidak berjalan lancar atau tidak selesai dengan baik.

Adapun yang menyebabkan kinerja karyawan PT. Haleyora Power menurun karena masih adanya karyawan yang merasa cemas pada saat melakukan pekerjaannya, karyawan yang kurang ramah pada konsumen, cendeung tidak serius saat bekerja, mudah marah, terlalu mementingkan pekerjaan orang lain, ceroboh dan cenderung gegabah dalam melakukan pekerjaan.

\section{Kinerja Karyawan}

Menurut Dewi (2015) ${ }^{[5]}$ kinerja merupakan salah satu kumpulan total dari kerja yang ada pada diri pekerja atas tugas yang diberikan. Kinerja merupakan suatu fungsi dan motivasi dan kemampuan untuk menyelesaikan tugas atau pekerjaan, seseorang harus mempunyai derajat kesediaan dan tingkat kemampuan, kinerja merujuk kepada tingkat keberhasilan dalam melaksanakan tugas serta kemampuan untuk mencapai tujuan yang telah ditetapkan. menurut Simamora (dalam Dewi, 2015) ${ }^{[5]}$ menyatakan kinerja adalah keadaan atau tingkat perilaku sseorang yang harus dicapai dengan persyaratan tertentu. Menurut Robbins (dalam Hari, 2019) ${ }^{[17]}$ kinerja merupakan pencapaian yang optimal sesuai dengan potensi yang dimiliki seseorang karyawan merupakan hal yang selalu menjadi perhatian para pemimpin organisasi. Kinerja ini menggambarkan sejauh mana aktivitas seseorang dalam melaksanakan tugas dan berusaha dalam pencapaian tujuan yang ditetapkan.

\section{Dimensi-dimensi Kinerja Karyawan}

Menurut Robbins (dalam Hari, 2019) ${ }^{[17]}$ indikator untuk mengukur kinerja karyawan secara individu yaitu :

a. Kualitas, kualitas erja diukur dari persepsi karyawan terhadap kualitas pekerjaan yang dihasilkan serta kesempurnaan tugas terhadap keterampilan dan kemampuan karyawan.

b. Kuantitas, merupakan jumlah yang dihasilkan dinyatakan dalam istilah seperti jumlah unit, jumlah siklus aktivitas yang diselsaikan.

c. Ketepatan waktu, merupakan tingkat aktivitas diselesaikan pada awal waktu yang dinyatakan dilihat dari sudut koordinasi dengan hasil outpur serta memaksimalkan waktu yang tersedia untuk aktivitas lain.

d. Efektivitas, merupakan tingkat penggunaan sumber daya organisasi (tenaga, uang, teknologi, bahan baku) dimaksimalkan dengan maksud menaikkan hasil dari setiap uni dalam penggunaan sumber daya. 
e. Kemandirian, merupakan tingkat seorang karyawan yang nantinya akan dapat menjalankan fungsi kerjanya komitmen kerja. Merupakan suatu tingkat dimana karyawan mempunyai komitmen kerja dengan instansi dan tanggung jawab karyawan terhadap kantor.

\section{Kepribadian Agreeableness}

Menurut Costa dan McCrae (dalam Feist dan Feist, 2008) ${ }^{[8]}$. agreeableness merupakan bagian dari suatu sistem motivasional seseorang yang berasal dari proses regulasi diri dimana seseorang terdorong untuk mendapatkan keintiman, persatuan dan solidaritas dengan kelompoknya. Agreeableness juga disebut social adaptability, menunjukkan orang yang murah hati, ramah, rendah hati, suka mengalah, menghindari konflik, dan memiliki kecendrungan untuk mengikuti orang lain. Menurut Barric (dalam Dewi, 2015) ${ }^{[5]}$ agreeableness adalah kepribadian yang dimiliki individu yang dominan memiliki karteristik baik hati, pemaaf, sopan, penolong, murah hati, ceria, dan bisa diajak bekerja sama. Kepribadian Agreeableness adalah kecenderungan seseorang untuk berperilaku kooperatif, mudah percaya, dan menghargai orang lain, dan sering dikaitkan dengan kemampuan adaptasi sosial, pribadi yang menyenangkan, dan juga pribadi yang penyanyang, John \& Srivastava (dalam Winastu, 2018) ${ }^{[22]}$.

\section{Dimensi Kepribadian Agreeableness}

Costa dan McCrae (dalam Fatmawati, 2017) ${ }^{[6]}$ menyebutkan dimensi agreeableness ada enam, yaitu:

a. $\quad$ Trust (Percaya)

Trust atau kepercayaan dapat didefenisikan sebagai atribut niat baik seseorang terhadap orang lain. Percaya yang terbaik dari orang lain dan jarang mencurigai maksud yang tersembunyi.

b. Straightforwardness (Terus terang)

Straightforwardness menunjukkan sifat keterusterangan dan kejujuran dalam berurusan dengan orang lain. Berterus terang, sungguh-sungguh, jujur dalam berurusan dengan orang lain.

c. Altruism (Hangat)

Altruism adalah tidak mementingkan diri sendiri dan kepedulian terhadap orang lain. Altruism cenderung kepada pengorbanan diri sendiri untuk kepentingan orang lain dan lebih mempertimbangkan orang lain. tidak mementingkan diri sendiri, peduli terhadap orang lain dan selalu memiliki keinginan untuk membantu orang yang sedang kesulitan.

d. Compliance (Kerelaan)

Compliance adalah gaya interpersonal yang terlihat ketika konflik muncul, individu cenderung mengalah dengan orang lain dari pada bertengkar. Dalam arti positif, sifat ini terlihat dalam kesediaan untuk bekerja sama. tidak mementingkan diri sendiri, peduli terhadap orang lain dan selalu memiliki keinginan untuk membantu orang yang sedang kesulitan.

e. Modesty (Kesederhanaan)

Modesty atau kesederhanaan, mengacu pada aspek dari konsep diri dimana mereka tidak sibuk dengan diri mereka sendiri. kesederhanaan atau kerendahan hati, orang yang menyenangkan adalah orang yang rendah hati, mampu menunjukkan kesederhanaannya dalam penilaan terhadap kemampuan dan kepentingan diri sendiri. Orang yang rendah hati cenderung memiliki nilai yang rendah dalam sikap narsistik, serta tidak sibuk dengan dirinya sendiri. Kebalikannya adalah orang yang sombong memiliki pandangan ingin meningkatkan dirinya sendiri. 


\section{f. Tender-mindedness (Kelembutan)}

Tender-mindedness mengacu pada kecenderungan untuk mengikuti perasaan, terutama dalam membuat penilaian dan bersikap. kepedulian terhadap orang lain yang akan diarahkan terutama dari perasaan empati, dalam membuat penilaan dan membentuk sikap. Orang yang menyenangkan adalah orang yang menunjukkan tender-mindedness dan sentimentalitas dengan mudah untuk membantu dan beramal demi tujuan yang baik.

\section{Metode Penelitian}

Jenis penelitian ini adalah kuantitatif korelasional dengan variabel penelitian Menurut Sugiyono $(2014)^{[16]}$ variabel penelitian Kinerja Karyawan (Y) dan Variabel Independen, (X) Kepribadian Agreeableness. Populasi pada penelitian ini adalah seluruh karyawan PT. Haleyora Power Singkarak yang berjumlah 40 orang karyawan. Teknik pengambilan sampel dalam penelitian ini dengan menggunakan teknik Sampling Jenuh dimana semua anggota populasi dijadikan sebagai sampel penelitian (Sugiono, 2013) $)^{[16]}$.

Alat ukur yang digunakan dalam penelitian ini adalah skala Kepribadian Agreeableness dan skala Kinerja Karyawan. Menurut Azwar (2014) ${ }^{[3]}$, skala adalah daftar pernyataan yang akan mengungkap performansi yang menjadi karakter tipikal pada subjek yang diteliti, yang akan dimunculkan dalam bentuk respon-respon terhadap situasi yang dihadapi. Skala dalam penelitian ini memiliki format respon dengan lima alternatif jawaban. Skala yang digunakan dalam penelitian ini menggunakan format respon jawaban model Likert.

Skala penelitian akan melewati berbagai tahap analisis yaitu uji normalitas digunakan untuk mengetahui apakah populasi data terdistribusi normal atau tidak. Uji normalitas menggunakan uji kolmogorov-Smirnov. Uji linearitas bertujuan untuk mengetahui apakah dua variabel mempunyai hubungan yang linear atau tidak. Dua variabel dikatakan mempunyai hubungan yang linear bila signifikasi (linearty) kurang dari 0,05.

Selain itu dilakukan uji Validitas, sejauh mana ketepatan dan kecermatan suatu alat ukur dalam melakukan fungsi ukurnya (Azwar, 2014) ${ }^{[3]}$. Suatu item dapat dianggap valid jika berkorelasi signifikan terhadap skor total atau jika melakukan penilaian langsung terhadap koefisien korelasi bisa digunakan batas nilai berkriteria rxy 0,3 (Priyatno, 2008) ${ }^{[8]}$. Data skala dikatakan memiliki daya beda tinggi jika koefisien korelasi lebih besar atau sama dengan 0,3 (rxy 0,3) dan sebaliknya aitem skala dikatakan gugur jika koefisien korelasi lebih kecil dari 0,3 (rxy 0,3 ).

\section{Hasil Dan Pembahasan}

Koefisien Validitas skala Kepribadian Agreeableness dengan nilai corrected item-total correlation berkisar antara 0,316 sampai dengan 0,733, dengan reliabilitas 0,873 , validitas skala Kinerja Karyawan dengan nilai corrected item-total correlation berkisar antara 0,34 sampai dengan 0,712 , dengan reabilitas 0,932 .

Uji normalitas dalam penelitian ini menggunakan uji Kolmogorov-Smirnov. Menurut Santoso (dalam Dewi, 2015), menjelaskan output test of normality jika angka signifikansi (sig) $>\alpha=0,05$ maka data berdistribusi normal. Berdasarkan hasil pengolahan data dengan menggunakan program IBM SPSS 21.0, maka diperoleh hasil sebagai berikut: 
Tabel 1: Uji Normalitas Skala Kepribadian Agreeableness dan Kinerja Karyawan

\begin{tabular}{ccccc}
\hline Variabel & N & KSZ & P & Sebaran \\
\hline Kepribadian Agreeableness & 40 & 0.836 & 0,487 & Normal \\
\hline Kinerja Karyawan & 40 & 0.580 & 0,889 & Normal \\
\hline
\end{tabular}

Nilai signifikansi pada skala Kepribadian Agreeableness sebesar $\mathrm{p}=0,487$ dengan KSZ $=0,836$ hasil tersebut menunjukan bahwa nilai p >0,05, artinya sebaran skala Kepribadian Agreeableness terdistribusi secara normal, sedangkan untuk skala Kinerja Karyawan diperoleh nilai signifikansi sebesar $\mathrm{p}=0,889$ dengan $\mathrm{KSZ}=0,580$ hasil tersebut menunjukan bahwa nilai $\mathrm{p}>0,05$, artinya sebaran terdistribusi secara normal. Selanjutnya uji linearitas dapat dilihat pada tabel 2 berikut:

Tabel 2:Uji Linieritas Kepribadian Agreeableness dan Kinerja Karyawan

\begin{tabular}{cccccc}
\hline $\mathbf{N}$ & $\mathbf{R}$ & $\mathbf{D f}$ & Mean square & $\mathbf{F}$ & Sig \\
\hline 40 & 0,556 & 1 & 1670,525 & 18,353 & 0,001 \\
\hline
\end{tabular}

Berdasarkan tabel diatas, diperoleh nilai $\mathrm{F}=18,353$ dengan signifikansi sebesar $\mathrm{p}=0,001(\mathrm{p}<0,05)$, artinya varians pada skala Kepribadian Agreeableness dan Kinerja Karyawan tergolong linier.

Tabel 3: Hasil Uji Korelasi Antara Kepribadian Agreeableness dan Kinerja Karyawan

\begin{tabular}{ccccc}
\hline $\mathbf{P}$ & $(\boldsymbol{\alpha})$ & Nilai korelasi $(\mathbf{r})$ & R square & Kesimpulan \\
\hline $\mathbf{0 , 0 0 0}$ & 0,01 & 0,556 & 0,309 & $\begin{array}{c}\text { sig (2-tailed) } 0,000<0,01 \\
\text { level of significant }(\alpha), \\
\text { berarti hipotesis diterima }\end{array}$ \\
\hline
\end{tabular}

Berdasarkan hasil uji korelasi di atas, terdapat korelasi dengan arah positif antara Kepribadian Agreeableness dengan kinerja karyawan, yaitu sebesar 0,556. Arah positif mengartikan, semakin positif kepribadian Agreeableness seorang karyawan, maka semakin tinggi pula kinerja karyawan tersebut. Sebaliknya, semakin negatif kepribadian Agreeableness seorang karyawan, maka semakin rendah kinerja karyawan tersebut. Hal ini diperkuat dengan hasil uji signifikan dengan bantuan IBM SPSS versi 21.0. Didapatkan p-value pada kolom sig (2-tailed) 0,000 < 0,01 level of significant $(\alpha)$, dimana menurut Nugroho (dalam Dewi, 2015) Hipotesis diterima, artinya terdapat korelasi yang positif antara Kepribadian Agreeableness dengan kinerja karyawan di PT. Haleyora Power.

Tabel 4: Descriptive Statistic Kepribadian Agreeableness dan kinerja karyawan

\begin{tabular}{cccccc} 
& N & $\begin{array}{c}\text { Mini } \\
\text { mum }\end{array}$ & $\begin{array}{c}\text { Maxim } \\
\text { um }\end{array}$ & Mean & $\begin{array}{c}\text { Std. } \\
\text { Deviation }\end{array}$ \\
\hline Kepri badian Agreeableness & 40 & 97 & 130 & 114,68 & 9,396 \\
\hline Kinerja Karyawan & 40 & 105 & 147 & 127,48 & 11,771
\end{tabular}

Berdasarkan nilai mean hipotetik, maka dapat dilakukan pengelompokkan yang mengacu pada kriteria pengkategorisasian dengan tujuan menempatkan individu kedalam kelompok-kelompok yang terpisah secara berjenjang menurut suatu kontinum berdasarkan atribut yang diukur (Azwar, $2014)^{[3]}$ berdasarkan norma kategorisasi, diperoleh kategorisasi subjek penelitian pada variabel, Kepribadian Agreeableness dan Kinerja Karyawan sebagai berikut : 


\begin{tabular}{ccccc}
\multicolumn{2}{c}{ Tabel 5: Kategori Kepribadian Agreeableness dan kinerja karyawan } \\
Variabel & Range & Jumlah & Persentase (\%) & Kategori \\
\hline Kepribadian & $103-140$ & 35 & $87.5 \%$ & Positif \\
\cline { 2 - 5 } Agreeableness & $65-102$ & 5 & $12.5 \%$ & Negatif \\
\hline Kinerja & $128-169$ & 20 & $50 \%$ & Tinggi \\
\cline { 2 - 5 } karyawan & $86-127$ & 20 & $50 \%$ & Rendah
\end{tabular}

Berdasarkan tabel 4.12 di atas, dapat digambarkan bahwa $87.5 \%$ dari seluruh subjek penelitian memiliki kepribadian Agreeableness yang positif, 12.5\% memiliki kepribadian Agreeableness yang negatif. Sementara itu, dapat digambarkan bahwa 50\% dari seluruh subjek penelitian memiliki kinerja karyawan yang tinggi, 50\% memiliki kinerja karyawan yang rendah.

\section{Sumbangan Efektif}

Besar sumbangan variabel Kepribadian Agreeableness dan Kinerja Karyawan dengan menggunakan rumus koefisien determinan. Koefisien determinan adalah kuadrat dari koefisien korelasi yang dikali dengan $100 \%$. Berdasarkan rumus tersebut maka dapat ditentukan bahwa besarnya sumbangan Kepribadian Agreeableness terhadap kinerja karyawan adalah sebesar $31 \%$ dan $69 \%$ ditentukan oleh faktor lain. Faktor lain yang dapat mempengaruhi kinerja karyawan yaitu tekanan dan sikap pimpinan yang kurang adil dan wajar, waktu dan peralatan kerja yang kurang memadai, konflik antara pribadi dengan pimpinan atau kelompok kerja, balas jasa yang terlalu rendah, dan masalah-masalah keluarga seperti anak, istri, mertua dan lain-lain (hari, 2019).

\section{Pembahasan}

Berdasarkan hasil uji korelasi Product Moment (Pearson) yang dilakukan dengan bantuan IBM SPSS versi 21.0, dimana level of significant $(\alpha)$ 0,01 dan diperoleh $\mathrm{p}=0,000$ serta koefisien korelasi $(\mathrm{r})=0,556 . \mathrm{P}<0,01$ maka hipotesis diterima. Hal ini menunjukkan bahwa terdapat hubungan yang positif dan signifikan antara Kepribadian Agreeableness dengan kinerja karyawan PT. Haleyora Power Singkarak Sumatera Barat. Artinya bahwa semakin positif kepribadian Agreeableness, maka semakin tinggi pula kinerja karyawannya. Sebaliknya, semakin negatif kepribadian Agreeableness, maka semakin rendah kinerja karyawan.

Sedarmayanti (dalam Hari, 2019) ${ }^{[17]}$ kinerja adalah pencapaian atau prestasi berkenaan dengan seluruh tugas ynag dibebankan kepadanya. Standar kerja mencerminkan keluaran normal dari seorang karyawan yang berprestasi rata-rata, dan bekerja pada kecepatan atau kondisi normal Menurut Simamora (dalam Hari, 2019) ${ }^{[17]}$, bahwa terdapat hubungan antara kepribadian dengan kinerja karyawan yaitu, faktor Individual, faktor organisasi terdiri dari sumber daya, faktor psikologis yang mencakupi persepsi, attitude, personality, pembelajaran dan motivasi.

John (Dewi, 2010) ${ }^{[5]}$, bahwa kepribadian mempengaruhi pikiran, perasaan, hingga tingkah laku seseorang. Ini mengindikasikan bahwa sebuah pekerjaan atau pun jabatan harus dibebankan kepada seorang pekerja yang berkepribadian ideal agar pekerjaan tersebut dapat selesai dengan memuaskan Penilaian kinerja karyawan dikantor diharapkan dapat memacu semngat kerja para karyawan agar bida mendapatkan hasil yang lebih memuaskan dan melebihi standar atau 
ketentuan yang ditetapkan oleh perusahaan serta dapat meningkatkan kualitas kerja sehingga para karyawan dapat memperoleh perpanjangan masa kerja dan promosi jabatan yang lebih baik.

\section{Kesimpulan}

Berdasarkan hasil dan pembahasan yang telah dijelaskan, maka dapat ditarik kesimpulan yang sekaligus merupakan jawaban dari tujuan penelitian yaitu: Terdapat hubungan positif dan signifikan antara Kepribadian Agreeableness dengan Kinerja karyawan di Pt. Haleyora Power Singkarak Sumatera Barat. Semakin positif kepribadian Agreeableness maka semakin tinggi kinerja karyawan. Sebaliknya, semakin negatif kepribadian Agreeableness, maka semakin rendah kinerja karyawan.

Besarnya sumbangan efektif variabel kepribadian Agreeableness terhadap kinerja karyawan adalah sebesar $31 \%$ sedangkan $69 \%$ dipengaruhi oleh faktor lain.

\section{Referensi}

[1] Antoni, Alif Diol. 2015. Hubungan antara stres kerja dengan kinerja guru SMAN 2 Sungai Penuh. Skripsi. Universitas Putra Indonesia Padang

[2] Arikunto, Suharsimi. 2010. Prosedur Penelitian. Jakarta: PT Rineka Cipta.

[3] Azwar, S. 2014. Penyusunan Skala Psikologi. Edisi II. Yogyakarta: Pustaka Pelajar.

[4] Devita, Maria. 2017. Faktor-faktor Mempengaruhi Kinerja Karyawan Di Restaurant alpha Hotel Pekanbaru. Jurnal. Riau. Vol. 4 No. 2

[5] Dewi, Warih Pratika, 2015, Hubungan Antara Big Five Personality dengan Kinerja Karyawan Outsourcing. Skripsi. Universitas Islam Negeri Sunan Ampel Surabaya.

[6] Fatmawati. 2017. Hubungan Agreeableness (kebaikan hati) dan Forgiveness (Pemaafan) Pada Mahasiswa. Skripsi. Fakultas Psikologi dan Ilmu Budaya Universitas Islam Indonesia.

[7] Fattah, Hussein. 2017. Kepuasan Kerja dan Pegawai. Yogyakarta. Elmatera

[8] Feist, Jess and Gregory J. Feist. 2008. Theories Of Personality. United States Of America: McGraw-Hill

[9] Hastuti, Upik Maria. 2014. "Analisis Kualitas Pelayanan Teknik Area Karang Tahun 2014 (Studi Pada PT Bermosacaro Selases Dijinal (BSD) Sebagai Mitra PT PLN (Persero) Area Karang)". Jurnal: Bandar Lampung.

[10] Indarti, S, Susi., dan Mahda, M. (2014). Pengaruh Faktor Kepribadian Pegawai dan Lingkungan Kerja terhadap Kinerja Pegawai pada Kantor Regional XII BKN Pekanbaru. Jurnal Ekonomi, Vol. 22, No. 1, 1-16.

[11] Khan, Abdul Waris. 2014. "Peran Perseroan Terbatas Perusahaan Listrik Negara Dalam Mewujudkan Pelayanan Publik Terhadap Ketersediaan Tenaga Listrik Berdasarkan Undang Undang Nomor 30 Tahun 2009 ( Studi Kasus: PT PLN Rayon Panam Pekanbaru )”. Skripsi: Riau.

[12] Nasyroh, Muslim dan Rinanda Wikansari. 2017. Hubungan Antara Kepribadian (Big Five Personality Model) Dengan Kinerja Karyawan. Jurnal. Jakarta Selatan.

[13] Priyatno, Dwi. 2008. Mandiri Belajar SPSS: Bagi Mahasiswa dan Umum. Yogyakarta: MediaKom

[14] Rismawati dan Mattalata.2018. Evaluasi Kinerja, penilaian Kinerja atas Dasar Prestasi Kerja Berorientasi Kedepan. Makasar: Celebes Media Perkasa

[15] Setiawan, Kiki Cahaya. 2015. Pengaruh kerja terhadap Kinerja Karyawan Level Pelaksanaan di Divisi Operasi PT. Pusri Palembang. Jurnal. Palembang Vol. 1 No. 2 43-53 
[16] Sugiyono. 2013. Metode penelitian pendektan kualitatif kuantitatif dan R\&D. Bandung : Alfabeta.

[17] Sulaksono, Hari. 2019. Budaya Organisasi dan Kinerja. Yogyakarta: Deepublish

[18] Taylor. 2012. Relationship Between Personality (Openneess, Conscientiousness, Extraversion, Emotional, Stability) With Student Environmental Moral Behavior. Jurnal Of Environmental And Management. Vol.1.No.2

[19] Taufik, Risky Aprilansyah. 2016. "Pengaruh Kepemimpinan Dan Motivasi Terhadap Kinerja Karyawan Di PT. PLN (Persero) Area Pelayanan Dan Jaringan (APJ) Sukabumi”. Skripsi: Sukabumi.

[20] Uno, Hamzah B. dan Nina Lametenggo. 2014. Teori Kinerja dan Pengukurannya. Jakarta: Bumi Aksara

[21] Widhiastuti, Hardani. 2014. Big Five Personality Sebagai Prediktor Kreativitas dalam Meningkatkan Kinerja Anggota Dewan. Jurnal. Universitas Semarang

[22] Winastu. 2018. Hubungan Kepribadian Agreeableness Dan Conscientiousness Dengan Berbagai Pengetahuan. Skripsi. Fakultas Psikologi. Universitas Sanata Dharma Yogyakarta. 